DOI: $10.47743 /$ jss-2021-67-4-12

\title{
Buna-credinţă în contractele click-wrap
}

\section{Good Faith in Click-Wrap Contracts}

\author{
Sorin-Claude Modreanu ${ }^{1}$
}

Rezumat: Dreptul a avut dintotdeauna menirea de a răspunde necesităţilor societăţii, asigurând un cadru normativ raporturilor juridice desfăşurate în societate, care să imprime siguranţă circuitului civil. Evoluţia din ce în ce mai rapidă a tehnologiei reprezintă o provocare constantă pentru drept, care trebuie să-şi demonstreze capacitatea de adaptare şi să fie întotdeauna actual. Aşadar, într-o societate cu 4,9 miliarde de utilizatori internet (62\% din întreaga populaţie) este firesc faptul că interacţiunile dintre drept şi internet sunt tot mai dese şi mai importante. În prezentul articol este analizat unul dintre cele mai utilizate contracte încheiate prin intermediul internetului, şi anume contractul de tip clickwrap, în care consimţământul este exprimat prin simpla apăsare a unei căsuţe. Astfel, este de interes modul în care funcţionează principiul general al bunei-credinţe din materia contractuală în astfel de acte juridice, ce efecte are acesta din urmă şi cum se aplică în această situaţie.

Cuvinte-cheie: internet; contracte de tip click-wrap; principiul bunei-credinţe; adaptare; efecte

Abstract: Law was always destined to answer all the necesities of society, making sure that there is a legal framework for the legal relationships which take place in society, that would induce certainity to the legal field. The ever faster technological evolution is a constant test for law, which has to demonstrate its capacity to adapt and always stay actual. Thus, in a society with 4.9 billions of internet users (62\% of the entire population) it is only natural that interractions between law and internet are more frequent and important. In this article we analyze one of the most used remote contracts concluded through the internet, which is the click-wrap contract, in which the consent is expressed simply by clicking on an icon. Such, the way that the general contractual principle of good faith works in such legal acts, what are its effects and how it applies in this situation are of interest.

Keywords: internet; click-wrap contracts; the principle of good faith; adapt; effects

\section{Introducere}

Contractele sunt un motor indispensabil al evoluţiei noastre şi ne-au însoţit cu mult timp înainte să le cunoaştem relevanţa juridică în felul în care înţelegem

\footnotetext{
${ }^{1}$ Doctorand, Facultatea de Drept, Universitatea „Alexandru Ioan Cuza” din Iaşi, e-mail: modreanu.sorin@yahoo.com.
} 
astăzi acest lucru. Astfel, contractele sunt parte din natura umană, deoarece omul este o fiinţă socială ${ }^{2}$ şi interacţiunea dintre oameni este un reflex.

Prin urmare, stadiul actual al dezvoltării economice a societăţii noastre se datorează abilităţii oamenilor de a elabora şi de a încheia contracte. Felul, complexitatea şi ingeniozitatea contractelor au reflectat întotdeauna stadiul tehnologiei existente, al resurselor disponibile şi al capacităţii noastre de a le utiliza.

Structura contractuală actuală, ale cărei condiţii fundamentale sunt, mai mult sau mai puţin identice de secole, este actualmente confruntată cu provocarea pe care o reprezintă internetul. Dintr-o societate de 7,9 miliarde de oameni ${ }^{3}$, aproximativ 4,9 miliarde utilizează internetul ${ }^{4}(62 \%)$, ceea ce înseamnă că interacţiunile dintre ramura juridică a contractelor şi internet vor fi din ce în ce mai dese şi mai intense.

În cuprinsul articolului vom încerca să stabilim dacă această nouă paradigmă a contractelor este în continuare compatibilă cu imemorialul principiu al buneicredințe, care are o importanţă deosebită în materia contractelor, dar care ar putea fi pus la îndoială în contextul contractelor de tip click-wrap.

\section{Contracte (buna-credinţă în contracte)}

Iată şi motivul pentru care acest studiu prezintă relevanţă. Deşi imaginea pe care o avem când ne gândim la încheierea contractelor diferă enorm în funcţie de perioada la care ne raportăm (tradiţiunea în antichitate, o înţelegere verbală, o strângere de mână sau un alt gest ritualic, redactarea unui înscris sub semnătură privată, un click pe un ecran), principiul general al bunei-credinţe, de această dată, privit în materia contractelor, le-a însoţit întotdeauna.

Întâi, într-o manieră foarte reducţionistă, un contract reprezintă legea părţilor. Acestea consimt la anumite prestaţii, la modul în care vor fi executate şi alte aspecte privitoare la raportul juridic pe care l-au creat în acest fel. Având în vedere caracterul esenţialmente privat, în care părţile ajung singure la un acord care creează efecte juridice, este necesar, pe de o parte, să explicăm încrederea mutuală pe care şi-o acordă părţile şi pe de altă parte, un mecanism care să le protejeze de eventuale abuzuri.

Răspunsul la ambele întrebări este buna-credinţă. Doctrina defineşte în general buna-credinţă din două puncte de vedere, cel obiectiv şi cel subiectiv 5 . Astfel, „,a stare psihologică a unui subiect de drept individual, se manifestă pe plan juridic, pe de o parte, sub forma intenţiei drepte, a diligenţei, a liceităţii şi abţinerii de la producerea vreunui prejudiciu în executarea obligaţiilor, în general, şi a contractelor în special. Pe de altă parte, buna-credinţă îmbracă forma erorii

2 Aristotel, Politica, Cartea I, Redactor Nicolae Năstase, Editura Antet, Oradea, 1996, p. 4.

3 [Online] la https://www.worldometers.info/world-population/, accesat 26.10.2021.

4 [Online] la https://datareportal.com/global-digital-overview, accesat 26.10.2021.

${ }^{5} \mathrm{~S}$. Tisseyre, Le rôle de la bonne foi en droit des contrats, Essai d'analyse à la lumière du droit anglais et du droit européen, Editura Presses Universitaires d'Aix Marseille, Aix-enProvence, 2012, p. 26. 
scuzabile, adică a convingerii eronate şi neculpabile a unei persoane că are un drept şi că acţionează potrivit legii. În primul caz, malitiis non est indulgendum, legea sancţionează în diferite moduri reaua-credinţă ca act opus bunei-credinţe. În al doilea, eroarea scuzabilă, protejată ca atare de lege, echivalează cu un drept care înseamnă ocrotirea persoanei de bună-credinţă în contra consecinţelor iregularităţii unui act juridic"6.

Aşadar, parte a principiului bunei-credinţe sunt comportamentul unei persoane care se circumscrie unor valori precum moralitatea, echitatea şi loialitatea, şi convingerea unei persoane că acţionează în mod just şi fără să prejudicieze interesele altuia, necunoscând aspectele care i-ar schimba această percepţie asupra situaţiei.

În cadrul prezentului studiu ne vom concentra atenţia asupra primei dimensiuni a acestui principiu, cea a bunei-credinţe obiective, aceasta fiind, în opinia noastră, relevantă din perspectiva compatibilităţii contractelor click-wrap cu principiul bunei-credinţe.

În dreptul român, principiul bunei-credinţe este afirmat întâi ca principiu general al ansamblului reglementării, situându-se în art. 14 C.civ. ${ }^{7}$, iar mai apoi ca principiu contractual, în art. 1170 C.civ. ${ }^{8}$ şi ca obligaţie în etapa negocierilor precontractuale, în art. 1183 C.civ. ${ }^{9}$ Preocuparea legiuitorului pentru bunacredinţă, din momentul redactării noului Cod civil, este astfel evidentă.

Este necesar a lămuri câteva aspecte legate de conţinutul concret al acestei noţiuni. Astfel, s-a afirmat în doctrină că o prima obligaţie care se circumscrie principiului contractual al bunei-credinţe este cea de loialitate, care se traduce prin îndatorirea părţilor „de a se informa reciproc, adică de a prezenta toate datele şi elementele necesare pentru formarea în bune condiţii a contractului” ${ }^{10}$. La aceasta

${ }^{6}$ I. Deleanu, S. Deleanu, Mică enciclopedie a dreptului, Editura Dacia, Cluj-Napoca, 2000, p. 108-110 și 210-211; D. Gherasim, Buna-credință, p. 34, 35, apud F.A. Baias, E. Chelaru, R. Constantinovici, I. Macovei (coordonatori), Noul Cod civil, Comentariu pe articole, ediția a 2-a, Editura C.H. Beck, București, 2014, p. 22.

7 „(1) Orice persoană fizică sau persoană juridică trebuie să ișsi exercite drepturile și obligațiile cu bună-credință, in acord cu ordinea publică și bunele moravuri.

(2) Buna-credință se prezumă până la proba contrară”.

8 „Părțile trebuie să acționeze cu bună-credință atât la negocierea și încheierea contractului, cât și pe tot timpul executării sale. Ele nu pot înlătura sau limita această obligație”.

${ }^{9}$ „(1) Părțile au libertatea inițierii, desfășurării și ruperii negocierilor și nu pot fi ținute răspunzătoare pentru eșecul acestora.

(2) Partea care se angajează într-o negociere este ținută să respecte exigențele buneicredințe. Părțile nu pot conveni limitarea sau excluderea acestei obligații.

(3) Este contrară exigențelor bunei-credințe, între altele, conduita părții care inițiază sau continuă negocieri fără intenția de a încheia contractul.

(4) Partea care inițiază, continuă sau rupe negocierile contrar bunei-credințe răspunde pentru prejudiciul cauzat celeilalte părți. Pentru stabilirea acestui prejudiciu se va ține seama de cheltuielile angajate în vederea negocierilor, de renunțarea de către cealaltă parte la alte oferte și de orice împrejurări asemănătoare”.

${ }^{10}$ F.A. Baias, E. Chelaru, R. Constantinovici, I. Macovei (coordonatori), op. cit., p. 1297. 
s-ar adăuga, conform unei opinii, obligaţia de cooperare ${ }^{11}$ a părţilor care înseamnă asigurarea unei echilibrări a prestaţiilor ${ }^{12}$ şi conlucrarea acestora în sens de ius fraternitatis, în spiritul solidarităţii ${ }^{13}$.

Cât despre conţinutul abstract al principiului bunei-credinţe, este mult mai larg şi într-o eternă schimbare, raportându-se la etică şi la morală, care evoluează concomitent cu societatea. În această dimensiune se circumscriu noţiuni precum corectitudine, solidaritate, deschidere şi mai ales încredere în „Celălalt"14. Ultima dintre noţiuni este indisolubil legată de spiritul contractului, şi anume de legătura privată dintre contractanţi. Părţile decid să dea naştere raportului juridic plecând de la prezumţia că cealaltă parte este sinceră, nu are alte intenţii decât cele menţionate şi convenite sau subînţelese şi că executarea contractului se va desfăşura în condiţii normale fără să fie nevoie de alte constrângeri pentru a determina partea să-şi respecte obligaţiile asumate. Aceasta este prezumţia relativă ${ }^{15}$ de bunăcredinţă, „bona fides praesumitur" ${ }^{16}$, care ne salvează dintotdeauna de un formalism excesiv, cronofag şi nenatural (să fie oare aceste caracteristici negative puse sub semnul întrebării de apariţia aşa numitelor smart contracts ${ }^{17}{ }^{18}$ ).

Iată deci o imagine generală şi mult simplificată a modului în care funcţionează principiul bunei-credinţe în materie contractuală.

\section{Contractele click-wrap}

Enunţăm faptul că, noile contracte click-wrap sunt contracte electronice şi contracte de adeziune.

În epoca internetului, s-a dezvoltat, în mod logic, o nouă tehnică de contractare ${ }^{19}$, şi anume contractul electronic.

„Contractul electronic ar putea fi definit ca fiind contractul încheiat la distanţă, între absenţi, care, ca orice contract, presupune realizarea acordului de voinţe ale părţilor contractante, cu intenţia de a stabili, modifica sau de a stinge un

${ }^{11}$ I. Adam, A.R. Adam, Codul civil. Cartea a V-a. Despre obligații, Titlurile I-VIII (art. 11641649), Comentarii și explicații, Editura C.H. Beck, București, 2016, p. 55.

${ }^{12}$ L. Pop, Tratat de drept civil. Obligațiile, volumul al II-lea, Contractul, Editura Universul juridic, București, 2009, p. 517, apud I. Adam, A.R. Adam, op. cit., p. 55.

${ }^{13}$ Ibidem.

${ }^{14}$ V.M. Ciucă, Bona fides într-o nouă hermeneutică, în volumul Simpozionului „Disponibilități creative în lume”, Societatea „Vasile Pogor”, Iași, 2009, p. 14.

${ }^{15}$ I. Adam, A.R. Adam, op. cit., p. 54.

${ }^{16}$ Ibidem.

${ }^{17}$ C.T. Ungureanu, Drept internațional privat european în raporturi de comerț internațional, Editura Hamangiu, București, 2021.

${ }^{18}$ I.-C. Leaua, prelegerea Noile tehnologii și frontiere ale principiului legalității, intervenție în cadrul Conferinței Naționale Ipostaze ale principiului legalității în dreptul național și european, 29.10.2021. S-a formulat opinia conform căreia în situația smart contracts, având în vedere modul în care operează acestea prin intermediul tehnologiei blockchain, prezumția este una de rea-credință, contrar modelului clasic.

${ }^{19}$ C.T. Ungureanu, Contractul electronic, Revista Dreptul, nr. 9, 2015, p. 159. 
raport juridic concret, specific fiind modul de exprimare a acordului, în forma înscrisului electronic"20. Contractul electronic este reglementat în România prin două legi ${ }^{21}$, şi anume Legea nr. 365/2002 din 7 iunie 2002, republicată, privind comerţul electronic ${ }^{22}$ şi Legea nr. 455/2001 din 18 iulie 2001, republicată, privind semnătura electronică ${ }^{23}$. Prin urmare, noţiunea de înscris în formă electronică este definită în această din urmă lege, la art. 4, pct. 2, ca fiind „o colecţie de date în formă electronică între care există relaţii logice şi funcţionale şi care redau litere, cifre sau orice alte caractere cu semnificaţie inteligibilă, destinate a fi citite prin intermediul unui program informatic sau al altui procedeu similar".

Conform alin. (1) al art. 7 din Legea nr. 365/2002 din 7 iunie 2002, republicată, privind comerţul electronic, contractelor încheiate prin mijloace electronice li se recunosc aceleaşi efecte precum contractelor obişnuite, „atunci când sunt întrunite condiţiile cerute de lege pentru validitatea acestora". Conform alin. (3) al aceluiaşi articol, regimul probei încheierii unor astfel de contracte este supus dispoziţiilor Legii nr. 455/2001 din 18 iulie 2001, republicată, privind semnătura electronică. Art. 9 din Legea nr. 365/2002 din 7 iunie 2002, republicată, privind comerţul electronic prevede momentul încheierii contractului, stabilind la alin. (1) că acesta este cel al ajungerii acceptării ofertei de a contracta la cunoştinţa ofertantului. Alin. (2), însă, derogă de la regula generală în ceea ce priveşte momentul încheierii contractului, stabilind că în situaţia contractului „care, prin natura sa ori la cererea beneficiarului, impune o executare imediată a prestației caracteristice se consideră încheiat în momentul în care debitorul acesteia a început executarea, în afară de cazul în care ofertantul a cerut ca în prealabil să $i$ se comunice acceptarea. În acest ultim caz se aplică prevederile alin. (1)”. Astfel se consacră teoria informaţiei, care derogă de la regula de drept comun pe care o reprezintă teoria recepţiei ${ }^{24}$.

Observăm faptul că în principiu, derogările de la dreptul comun, reprezentat de actualul Cod civil, sunt punctuale şi nu afectează esenţa contractului (capacitate, consimţământ, obiect, cauză ${ }^{25}$ ), deci cel puţin sub aspectul definiţiei, există o similaritate între contractele electronice şi cele clasice ${ }^{26}$.

Conform art. 1175 C.civ., contractul de adeziune este acea convenţie a cărei clauze „esenţiale sunt impuse ori sunt redactate de una dintre părţi, pentru aceasta sau ca urmare a instrucţiunilor sale, cealaltă parte neavând decât să le accepte ca atare". Principalele caracteristici ale acestor contracte sunt inegalitatea economică a părţilor, caracterul general dar detaliat al ofertei şi atribuirea redactării clauzelor

${ }^{20}$ Idem, p. 162.

${ }^{21}$ Idem, p. 160.

22 Publicat în M. Of. nr. 959 din 29 noiembrie 2006.

${ }^{23}$ Publicat în M. Of. nr. 316 din 30 aprilie 2014.

${ }^{24}$ C.T. Ungureanu, Contractul electronic ..., p. 173.

${ }^{25}$ L. Pop, I.-F. Popa, S.I. Vidu, Drept civil. Obligațiile, Ediția a II-a, revizuită și adăugită, Editura Universul Juridic, București, 2020, p. 56.

${ }^{26}$ D. Gărăiman, De la contractul clasic la contractul electronic, în Codul civil român între tradiție și reformă la 140 de ani de aplicare, în Revista Științe Juridice, 2006, p. 142, [Online] la https://drept.ucv.ro/RSJ/images/articole/2006/RSJ1/0119GaraimanD.pdf, accesat 29.10.2021. 
esenţiale unei singure părţi ${ }^{27}$. Specificul unui contract ca fiind de adeziune atrage, atunci când un profesionist contractează cu un consumator, incidenţa legislaţiei în materie $^{28}$. Astfel, „art. 4 alin. (1) din Legea nr. 193/2000 privind clauzele abuzive din contractele încheiate între profesionişti şi consumatori, republicată, prevede că o clauză abuzivă este acea clauză care nu a fost negociată direct cu consumatorul şi care, prin ea însăşi sau împreună cu alte prevederi din contract, creează, în detrimentul consumatorului şi contrar cerinţelor bunei-credinţe, un dezechilibru semnificativ între drepturile şi obligaţiile părţilor”29.

Aceste noţiuni fiind explicate, ne vom apleca asupra contractelor click-wrap, care sunt, dintr-o subclasificare a contractelor electronice ${ }^{30}$, ,acele contracte de adeziune pentru încheierea cărora destinatarul unei oferte făcute online (pe Internet) trebuie doar să bifeze, într-o casetă (să facă un simplu click pe o pictogramă), butonul „Da”, „I accept”, „Yes” sau „I agree” ori altul similar şi contractul se perfectează" ${ }^{\prime \prime}$.

Având în vedere modalitatea specifică de exprimare a consimţământului, pot exista discuţii cu privire la validitatea unui consimţământ astfel exprimat. În acest sens, s-a afirmat în doctrină că „un gest neechivoc sau un comportament activ poate fi considerat ca o manifestare expresă a voinţ̧ei acceptantului. Pe de altă parte, pentru ca un contract să fie valabil format trebuie ca utilizatorul (acceptantul) să fie conştient că gestul său înseamnă admiterea efectivă a dispoziţiilor contractului de adeziune propus. Este motivul pentru care oferta trebuie să conţină toate datele particulare ale contractului" ${ }^{32}$. Aşadar, în materia contractelor click-wrap, depinde de iscusinţa (sau de buna-credinţă) a celor care redactează clauzele contractului pentru ca exprimarea consimţământului aderentului, în forma propusă de către cei dintâi, să producă efectele juridice prefigurate. Există suficiente metode la îndemâna celor care redactează contractul pentru a se asigura de acest lucru, iar cel mai important aspect este de a construi mecanismul în aşa fel încât să ofere anumite garanţii ale faptului că ansamblul dispoziţiilor contractuale a ajuns la cunoştinţa aderentului, fapt care poate fi realizat prin utilizarea unui limbaj explicit, prin plasarea pictogramei prin apăsarea căreia se manifestă acceptul aderentului la finalul documentului care conţine clauzele contractuale şi inclusiv prin plasarea întregului ansamblu de dispoziţii contractuale într-un singur loc.

Astfel, cum este situaţia majorităţii legislaţiilor, şi în România, din anul 2007, este recunoscută (de către ÎCCJ) exprimarea consimţământului prin contracte click$w_{r a p}{ }^{33}$. Discuţiile şi nuanţările făcute în paragraful anterior rămân valabile, iar criteriile specifice urmează a fi decelate în doctrină şi în jurisprudenţă.

\footnotetext{
${ }^{27}$ I. Adam, A.R. Adam, op. cit., p. 81.

${ }^{28}$ F.A. Baias, E. Chelaru, R. Constantinovici, I. Macovei (coordonatori), op. cit., p. 1303.

${ }^{29}$ Idem, p. 1304.

${ }^{30}$ C.T. Ungureanu, Contractul electronic ..., pp. 164-165.

${ }^{31}$ Idem, p. 165.

${ }^{32}$ D. Gărăiman, op. cit, p. 148.

${ }^{33}$ C.T. Ungureanu, Contractul electronic ..., p. 174.
} 
Spre exemplu, în doctrina din Statele Unite, s-a constatat că partea care a redactat contractul de adeziune (în acest exemplu, fiind vorba în special de contractele online) introduce deseori în contract clauze favorabile ei dar nerezonabile, mizând pe faptul că aderentul nu va citi contractul şi va da un consimţământ valabil pentru întregul contract ${ }^{34}$.

\section{Buna-credinţă în contractele click-wrap}

Întrebarea pe care ne-o punem în acest context este dacă prevalenţa contractelor de tip click-wrap ne îndepărtează de principiul străvechi (dar uman şi necesar) al bunei-credinţe, sau dacă principiul este doar pliat în mod convenabil pe caracteristicile inedite (sau nu?) ale acestui tip de contract.

Astfel, pentru a răspunde la această întrebare, am încadrat contractul clickwrap în categoria contractelor electronice şi în specia contractelor de adeziune. În consecinţă, pentru trăsăturile pe care le împrumută de la aceste două apartenenţe, nu există motive ca principiul bunei-credinţe să fie pus la îndoială, în orice caz nu mai mult decât pentru situaţia separată a contractelor electronice şi a contractelor de adeziune în sine. Există însă anumite precizări care pot fi făcute.

În primul rând, „în prezent, părţile, într-o societate în care totul se desfăşoară cu viteză, nu se mai întâlnesc faţă în faţă, mai ales în cazul contractelor în care una dintre părţi este consumator" 35 . Contractele click-wrap, fiind contracte electronice, se încheie la distanţă, între absenţi. Aşa fiind, se poate pune problema, aşa cum a fost afirmat în doctrină, în legătură cu faptul că, în materie contractuală, „cunoaşterea identităţii cocontractantului este un element determinant al raporturilor contractuale pe care utilizatorul doreşte să le folosească"36. După cum am menţionat anterior, un aspect care ţine de principiul bunei-credinţe este acela al încrederii prezumate în cocontractant. Pentru a întări sentimentul de încredere, este important ca partea să-şi cunoască, atât cât este rezonabil posibil, cocontractantul. Este mult mai uşor pentru un om să se încreadă într-o figură pe care a văzut-o, decât în una pe care nu poate decât să şi-o imagineze. Deşi acesta este un aspect care poate fi întâlnit deseori în contractele între absenţi, în contractele click-wrap acesta va fi cazul mereu. Chiar şi în contractele pe care le încheie consumatorii cu profesioniştii, în care de multe ori aceştia nu iau contact decât cu un prepus al acestora din urmă, există o minimă interacţiune umană care poate fi de natură să stimuleze încrederea în aceştia. Deşi nu este un aspect determinant, este totuşi o limitare a înţelesului principiului bunei-credinţe. Se

${ }^{34}$ E.A. Zacks, The restatement (Second) of contracts $\$ 211$ : Unfulfilled expectations and the future of modern standardized consumer contracts, în Wayne State University Law School Legal Studies Research paper series no. 2016-14, pp. 736-738, [Online] la https://scholarship. law.wm.edu/wmblr/vol7/iss3/4/, accesat 26.10.2021.

${ }^{35}$ C.T. Ungureanu, Implicațiile internetului în viața juridică, în Analele Științifice ale Universității „Alexandru Ioan Cuza” Iași, Tomul LXIII, Științe Juridice, 2017, nr. II, p. 2.

${ }^{36}$ D. Gărăiman, op. cit., p. 143. 
vorbeşte în doctrină despre „depersonalizarea, dematerializarea şi delocalizarea schimburilor prin internet" 37 .

În al doilea rând, fiind în discuţie conţinutul concret al principiului buneicredinţe, clauzele contractuale nu sunt şi nu pot fi negociate. Dacă am considera acest aspect ca fiind o atingere adusă principiului bunei-credinţe, atunci în orice caz nu ar fi una inedită, deoarece aceasta este situaţia contractelor de adeziune care sunt reglementate de mult timp şi şi-au păstrat acest caracter indiferent de modul în care a fost reglementat sau înţeles principiul bunei-credinţe. Aşadar, deşi acestea pot ridica anumite probleme în ceea ce priveşte buna-credinţă, neajunsurile sunt contrabalansate, cel puţin teoretic, de avantajele pe care le implică, precum rapiditatea întregii activităţi de contractare ${ }^{38}$. Într-o piaţă liberă şi extrem de dinamică, precum cea actuală, ar fi imposibil de imaginat ca fiecare contract încheiat pentru nevoi sau activităţi curente (mai ales pentru cele de o valoare economică redusă) să fie negociat. Ar fi o activitate extrem de cronofagă.

Spre exemplu, optica sistemului de common law din Statele Unite, exprimată prin Restatement (Second) of Contracts, desprinsă din prevederile Secţiunii 211 a fost aceea că o persoană care îşi exprimă consimţământul pentru un contract de adeziune pentru consumatori va fi ţinută de termenii contractuali chiar dacă aceasta nu i-a citit ${ }^{39}$. Însă chiar şi în această situaţie, buna-credinţă îşi găseşte aplicabilitatea, dar sub altă formă. Astfel, consumatorul va ţine cont de faptul că profesionistul încheie un contract similar cu un mare număr de persoane ${ }^{40}$, şi „se va încrede în «buna-credinţă » a celui care a redactat contractul de adeziune"41. Trebuie precizat că în acelaşi articol din Secţiunea 211 din Restatement (Second) of Contracts, se menţionează şi faptul că atunci când profesionistul consideră că un consumator n-ar fi contractat dacă ar fi ştiut de existenţa unei anumite clauze, acea clauză nu va fi aplicabilă, completând în acest fel un oarecare echilibru între cele două părţi ${ }^{42}$.

De asemenea, în contractele electronice, există o obligaţie de informare (art. 5 şi art. 8 din Legea nr. 365/2002 din 7 iunie 2002, republicată, privind comerţul electronic şi, pentru situaţia în care se contractează cu un consumator în calitatea acestuia de destinatar al serviciilor, O.U.G. nr. 34/2014, din 4 iunie 2014, privind drepturile consumatorilor în cadrul contractelor încheiate cu profesioniştii, precum şi pentru modificarea şi completarea unor acte normative ${ }^{43}$ ), sub sancţiunea nulităţii relative (art. 21 din Legea nr. 365/2002 din 7 iunie 2002, republicată, privind comerţul electronic $)^{44}$.

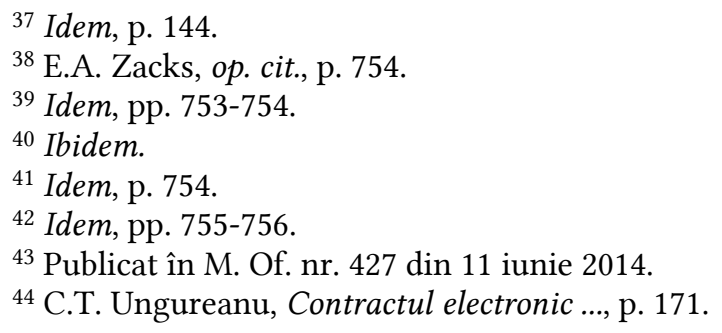


Prin urmare, deşi există anumite limitări ale principiului bunei-credinţe în cazul contractelor de adeziune, deci inclusiv în cele click-wrap, ţinând cont de faptul că între acestea sunt contracte încheiate între profesionişti şi consumatori, o contrabalansare a limitărilor aduse efectelor principiului bunei-credinţe este cea dată de aplicabilitatea protecţiei speciale a consumatorilor (în dreptul naţional şi european). O altă limitare ar fi cea impusă de reglementarea clauzelor standard în contractele de adeziune ${ }^{45}$.

\section{Drept comparat sau compatibilitate cu internaţionalitatea contractelor de tip click-wrap}

Având în vedere modul în care se încheie contractele de tip click-wrap şi circumstanţele specifice, în special faptul că cel care propune contractul de adeziune şi aderentul pot avea sediul respectiv domiciliul în state diferite, există o serie de precizări cu privire la legea aplicabilă contractului şi instanţa competentă să judece litigii izvorâte din contract ${ }^{46}$. Astfel, anumite state (cum sunt cele de common law, spre exemplu) înţeleg altfel principiul bunei-credinţe şi nu îl recunosc expres, ci doar indirect prin existenţa anumitor instituţii juridice cu efecte similare celor pe care le atribuie sistemele de drept continental în general principiului bunei-credinţe.

Deşi această ipoteză nu este singura posibilă, ne vom limita la a expune situaţia în ceea ce priveşte autoritatea competentă să soluţioneze un litigiu de drept internaţional privat izvorât dintr-un contract de tip click-wrap şi legea aplicabilă acestui raport juridic, când instanţa sesizată este cea română, autoritatea competentă să soluţioneze litigiul (prin convenţia validă a părţilor sau conform regulilor aplicabile) este o instanţă de judecată, iar părţile sunt un profesionist stabilit întrun stat membru al Uniunii Europene şi un consumator cu reşedinţa obişnuită în România, deoarece aceste calităţi ale părţilor şi particularităţi ale raportului juridic sunt foarte des întâlnite în litigiile izvorâte din contracte de tip click-wrap.

Aşadar, instanţa competentă poate fi aleasă prin „convenţia părţilor sau din prezentarea şi apărările pârâtului (prorogarea voluntară de competenţă)" ${ }^{\prime 7}$ sau este stabilită conform normelor de competenţă aplicabile în temeiul legii forului ${ }^{48}$.

Instanţa română sesizată cu un astfel de litigiu va proceda întâi la „determinarea instanţei competente de a soluţiona litigiul" „Instanţa română are competenţă exclusivă în temeiul art. 1.080 C.pr.civ"50. Astfel, pct. 3 al art. 1.080 C.pr.civ. stabileşte că instanţa română este competentă pentru

${ }^{45}$ F.A. Baias, E. Chelaru, R. Constantinovici, I. Macovei (coordonatori), op. cit., p. 1303.

${ }^{46}$ C.T. Ungureanu, Contractul electronic ..., p. 179.

${ }^{47}$ C. Dariescu, Fundamentele dreptului internațional privat, Ediția a V-a, revăzută și adăugită, Editura Universul Juridic, București, 2018, p. 56.

${ }^{48}$ C.-N. Bărbieru, C. Dariescu, Fișe de drept internațional privat, Colecția Examene, Editura Universul Juridic, București, 2020, pp. 52, 53, 56, 57, 62.

${ }^{49}$ C. Dariescu, op. cit., p. 41.

${ }^{50}$ C.T. Ungureanu, Contractul electronic ..., p. 182. 
„contracte încheiate cu consumatori având domiciliul sau reşedinţa obişnuită în România, pentru prestații de consum curent destinate uzului personal sau familial al consumatorului şi fără legătură cu activitatea profesională sau comercială a acestuia, dacă: a) furnizorul a primit comanda în România; b) încheierea contractului a fost precedată în România de o ofertă sau o publicitate şi consumatorul a îndeplinit actele necesare încheierii contractului”. Astfel, „Competenţa exclusivă există atât pentru acţiunile introduse de consumator contra furnizorului cât şi invers" ${ }^{\prime}$.

Având în vedere acest temei de competenţă exclusivă şi art. 1.068 alin. (2) C.pr.civ. ${ }^{52}$, o eventuală convenţie de alegere a forului prin care părţile ar alege o altă instanţă decât cea română ca fiind competentă să judece litigiul în cazul unui contract click-wrap ar fi nulă ${ }^{53}$, deoarece nesocoteşte un temei de competenţă exclusivă a instanţelor române ${ }^{54}$.

Astfel, în ceea ce priveşte instanţa competentă, în ipoteza aleasă, întotdeauna va fi competentă instanţa română.

În ceea ce priveşte legea aplicabilă raportului juridic, există două ipoteze. Prima este cea în care se consideră că „regula tării de origine nu acoperă libertatea părţilor contractante de a alege legea aplicabilă contractului pe care l-au încheiat, care ar fi determinată potrivit normelor conflictuale din Roma I, nici obligaţiilor contractuale care privesc contracte încheiate cu consumatorii. Aceste obligaţii includ informaţii cu privire la elementele esenţiale ale contractului, inclusiv drepturi ale consumatorilor, care au o influență determinantă asupra deciziei de a contracta" ${ }^{55}$. Aşadar, acestor raporturi juridice li se aplică prevederile Regulamentului Roma I ${ }^{56}$. „Potrivit art. 6.1 Regulamentul Roma I, contractele încheiate între un consumator şi un profesionist sunt reglementate de legea statului în care îşi are reşedinţ̧a obişnuită consumatorul, cu condiţia ca profesionistul să-şi desfăşoare activitatea comercială sau profesională în ţara în care îşi are reşedinţa obişnuită consumatorul,

${ }^{51}$ C. Dariescu, op. cit., p. 56.

52 „Art. 1.068. Alegerea forului

(1) În materie patrimonială, părţile pot conveni asupra instanţei competente să judece un litigiu actual sau eventual izvorând dintr-un raport cu elemente de extraneitate. Convenţia poate fi încheiată prin înscris, telegramă, telex, telecopiator sau orice alt mijloc de comunicare ce permite a-i stabili proba printr-un text. In lipsă de stipulaţie contrară, competenţa forului ales este exclusivă.

(2) Alegerea instanţei este fără efect dacă ea conduce la lipsirea în mod abuziv a uneia dintre părţi de protecția pe care i-o asigură o instanţă prevăzută de legea română. De asemenea, alegerea este fără efect când instanţa aleasă este străină, iar litigiul este de competenţa exclusivă a instanţelor române, precum şi când instanţa aleasă este română, iar litigiul este de competenţa exclusivă a unei instanţe străine”.

${ }^{53}$ C.T. Ungureanu, Contractul electronic ..., p. 183.

${ }^{54}$ C. Dariescu, op. cit., pp. 57-58.

${ }^{55}$ A. Jaroszek, European online marketplace - new measures for consumer protection against "old conflict of laws rules", în Masaryk University Journal of Law and Technology, 2015, p. 30; DOI: https://doi.org/10.5817/MUJLT2015-1-3.

${ }^{56}$ C.T. Ungureanu, Drept internațional privat european în raporturi de comert internațional..., p. 98. 
fie, prin orice mijloace, să-şi direcţioneze activităţile către ţara în cauză sau către mai multe ţări, printre care şi ţara în cauză, şi ca respectivul contract să se înscrie în sfera activităţilor respective" ${ }^{77}$. Dacă nu sunt îndeplinite condiţiile privind desfăşurarea activităţii în ţara în care îşi are reşedinţă obişnuită consumatorul, sau cele privind direcţionarea acesteia către ţara în care îşi are reşedinţa obişnuită consumatorul, se aplică prevederile art. 3 şi art. 4 ale Regulamentului Roma I ${ }^{58}$. De asemenea, în contractele încheiate între profesionişti şi consumatori este posibilă, în temeiul Regulamentul Roma I, o convenţie prin care părţile aleg legea aplicabilă contractului ${ }^{59}$. Astfel, „potrivit art. 6 alin. (2), alegerea de către părţi a legii aplicabile unui contract care îndeplineşte condiţiile specificate în art. 6 alin. (1), nu poate avea ca rezultat privarea consumatorului de protecţia pe care i-o asigură dispoziţiile imperative ale legii ţării în care consumatorul îşi are reşedinţa obişnuită" ${ }^{60}$.

În a doua ipoteză, norma de drept internaţional privat din Legea nr. 365 din 7 iunie 2002, republicată, privind comerţul electronic ${ }^{61}$, care stabileşte legea aplicabilă raporturilor juridice pe care le reglementează această lege, este considerată una de aplicaţie imediată ${ }^{62}$. Astfel cum reiese din dispoziţiile art. 3 al Legii nr. 365 din 7 iunie 2002, republicată, privind comerţul electronic, lege care, aşa cum se precizează în dispoziţiile finale ale acesteia, „transpune Directiva 2000/31/CE referitoare la anumite aspecte juridice privind serviciile societăţii informaționale, în special comerţul electronic în piaţa internă, publicată în furnalul Oficial al Comunităţilor Europene $n r$. L 178/2000", serviciilor societăţii informaţionale li se aplică legislaţia statului în care este stabilit furnizorul, dacă acesta este stabilit într-un stat membru al Uniunii Europene. Astfel, inclusiv în ipoteza în care părţile au încheiat o convenţie prin care aleg legea aplicabilă raportului juridic, aceasta va fi aplicabilă numai dacă coincide cu legea statului în care este stabilit furnizorul ${ }^{63}$. Interpretând aceste dispoziţii, cele ale alin. (40) al Preambulului Regulamentului (CE) nr. 593/2008 al Parlamentului European şi al Consiliului din 17 iunie 2008 privind legea aplicabilă obligaţiilor contractuale

${ }^{57}$ Ibidem.

${ }^{58}$ Ibidem.

${ }^{59}$ Idem, p. 99.

${ }^{60}$ Ibidem.

${ }^{61}$ Art. 3. „Aplicarea legii române în cazul serviciilor societății informaționale. (1) Prezenta lege se aplică furnizorilor de servicii stabiliți în România și serviciilor oferite de aceștia. (2) De la data intrării în vigoare a prezentei legi serviciile societății informaționale sunt supuse: a) exclusiv prevederilor în vigoare ale legilor române care fac parte din legislația coordonată, $\hat{\imath}$ cazul în care sunt oferite de furnizori de servicii stabiliți în România; b) exclusiv prevederilor în vigoare ale legilor statului în cauză care fac parte din legislația coordonată, în cazul în care sunt oferite de furnizori de servicii stabiliți într-un stat membru al Uniunii Europene”; publicată în M. Of. nr. 959 din 29 noiembrie 2006.

${ }^{62}$ C.T. Ungureanu, Drept internațional privat european în raporturi de comerț internațional..., p. 391.

${ }^{63}$ C.T. Ungureanu, Contractul electronic ..., pp. 180-181. 
(Roma I) ${ }^{64}$ şi cele ale art. 9 al aceluiaşi Regulament, în ceea ce priveşte legea aplicabilă contractelor încheiate prin mijloace electronice se aplică prevederile Legii 365 din 7 iunie 2002, republicată, privind comerţul electronic. Deci, în ipoteza noastră, a contractului click-wrap, legea aplicabilă contractului va fi cea a statului membru al Uniunii Europene în care este stabilit furnizorul de servicii.

Iată deci cum legea aplicabilă unui contract de tip click-wrap încheiat în condiţiile pe care le-am enunţat poate fi supus legii unor state diferite. Aşadar, întrebarea care se poate pune în contextul prezentului articol este dacă acest lucru aduce atingere în orice fel modului în care influenţează principiul contractual al bunei-credinţe contractul propriu-zis.

In majoritatea statelor membre ale Uniunii Europene ${ }^{65}$, fiind sisteme de drept continental, principiul contractual al bunei-credinţe este cunoscut şi consacrat legislativ în forme asemănătoare. Aşadar, influenţa sa asupra unui astfel de contract este aceeaşi, indiferent de legea cărui stat european se va aplica.

În schimb, înaintea ieşirii Marii Britanii din Uniunea Europeană, era uşor de imaginat un contract click-wrap încheiat cu un consumator român căruia sa i se aplice legea Marii Britanii. Sistemele de common-law, dar mai ales cel britanic, nu recunosc existenţa unui principiu contractual al bunei-credinţe, întrucât contravine spiritului dreptului britanic aplecat către libertatea contractuală cvasiabsolută şi către diligenţa fiecărei părţi ${ }^{66}$. Această viziune este însă atenuată, cel puţin în privinţa efectelor, de instituţii care suplinesc necesitatea consacrării unui principiu general sau contractual al bunei-credinţe îndeplinind efectele acestuia. Aceste instituţii, ale căror efecte sunt asemănătoare celor pe care sistemele de drept continental le atribuie principiului bunei-credinţe, sunt promissory estoppel, unjust enrichment, misrepresentation ${ }^{67}$ şi efficient breach of contract ${ }^{68}$. Prin urmare, unui contract căruia i se aplică legea britanică, principiul contractual al bunei-credinţe din dreptul continental nu i se va aplica, dar va rămâne însă la adăpostul instituțiilor amintite.

${ }^{64}$ Publicat în Jurnalul Oficial al Uniunii Europene nr. L/177/6 în data de 4 iulie 2008.

${ }^{65}$ Spre exemplu, Codul civil francez, în art. 1104, astfel cum a fost modificat prin Ordonanța numărul 2016-131 din 10 februarie 2016, pentru reforma dreptului contractelor și a regimului general și al probei obligațiilor (traducerea ne aparține), publicat în M. Of. al Franței (f. O.) din 11 februarie 2016, reglementează principiul contractual al bunei-credințe. „(1) Contractele trebuie negociate, încheiate și executate cu bună-credință. (2) Această dispoziție este de ordine publică”.

${ }^{66}$ The Honorable Mr. Justice Steyn, The Role of Good Faith and Fair Dealing in Contract Law: A Hair-Shirt Philosophy?, The Royal Bank of Scotland Lecture, 1991, Oxford, published by arrangement with Mr. Justice Steyn and the Royal Bank of Scotland, p. 136.

${ }^{67}$ L. Péloquin, C. K. Assié, Droit contractuel - La lettre d'intention, în La Revue juridique Thémis (Québec), vol. 40, nr. 1/2016, pp. 192-193, apud. M. Floare, op. cit., p. 224.

${ }^{68}$ Idem, p. 322. 


\section{Concluzii}

Având în vedere cele prezentate în acest articol, considerăm că această nouă metodă de a contracta (contractele click-wrap) nu contravine principiului buneicredinţe, datorită anumitor elemente care contrabalansează limitările punctuale aduse acestui principiu.

Conţinutul concret al principiului bunei-credinţe se păstrează, cu mici excepţii, care nu sunt însă suficiente pentru a pune sub semnul întrebării acest principiu contractual. Cât despre conţinutul abstract, şi anume despre încrederea dintre contractanţi, există anumite nuanţări, dar şi acestea sunt fireşti, având în vedere structura inedită (dacă privim întreaga istorie a contractelor) a acestui tip de contract.

Aşadar, nu se impune, din punctul nostru de vedere, o analiză atentă a eficacităţii principiului bunei-credinţe în acest nou context, deoarece, în prezent, nu există incompatibilităţi importante în coexistenţa acestuia cu modul în care funcţionează contractele click-wrap.

\section{Referinţe}

Adam I., Adam A.R., Codul civil. Cartea a V-a. Despre obligaţii, Titlurile I-VIII (art. 1164-1649), Comentarii şi explicaţii, Editura C.H. Beck, Bucureşti, 2016

Aristotel, Politica, Cartea I, Redactor Nicolae Năstase, Editura Antet, Oradea, 1996

Baias F.A., Chelaru E., Constantinovici R., Macovei I. (coordonatori), Noul Cod civil, Comentariu pe articole, ediţia a 2a, Editura C.H. Beck, Bucureşti, 2014

Bărbieru C.-N., Dariescu C., Fişe de drept internaţional privat, Colecţia Examene, Editura Universul Juridic, Bucureşti, 2020

Ciucă V.M., Bona fides într-o nouă hermeneutică, în volumul Simpozionului „Disponibilităţi creative în lume”, Societatea „Vasile Pogor”, Iaşi, 2009

Dariescu C., Fundamentele dreptului internaţional privat, Ediţia a V-a, revăzută şi adăugită, Editura Universul Juridic, Bucureşti, 2018

Deleanu I., Deleanu S., Mică enciclopedie a dreptului, Editura Dacia, Cluj-Napoca, 2000

Gărăiman D., De la contractul clasic la contractul electronic, în Codul civil român între tradiţie şi reformă la 140 de ani de aplicare, în Revista Ştiinţe Juridice, 2006

Gherasim D., Buna-credinţă, p. 34, 35, apud Baias F.A., Chelaru E., Constantinovici R., Macovei I. (coordonatori), Noul Cod civil, Comentariu pe articole, ediţia a 2-a, Editura C.H. Beck, Bucureşti, 2014

Jaroszek A., European online marketplace - new measures for consumer protection against „old conflict of laws rules”, în Masaryk University Journal of Law and Technology, 2015; DOI https://doi.org/10.5817/MUJLT2015-1-3

Leaua I.-C., prelegerea Noile tehnologii şi frontiere ale principiului legalităţii, intervenţie în cadrul Conferinţei Naţionale Ipostaze ale principiului legalităţii în dreptul naţional şi european, 29.10.2021

Péloquin L., Assié C.K., Droit contractuel - La lettre d'intention, în La Revue juridique Thémis (Québec), vol. 40, nr. 1/2016, pp. 192-193, apud Floare M., Buna şi reaua-credinţă în negocierea şi executarea contractelor de drept comun, în noul cod civil şi în dreptul comparat, Editura Universul Juridic, Bucureşti, 2015

Pop L., Popa I.-F., Vidu S.I., Drept civil. Obligaţiile, Ediţia a II-a, revizuită şi adăugită, Editura Universul Juridic, Bucureşti, 2020 
Pop L., Tratat de drept civil. Obligaţiile, volumul al II-lea, Contractul, Editura Universul juridic, Bucureşti, 2009

The Honorable Mr. Justice Steyn, The Role of Good Faith and Fair Dealing in Contract Law: A Hair-Shirt Philosophy?, The Royal Bank of Scotland Lecture, 1991, Oxford, published by arrangement with Mr Justice Steyn and the Royal Bank of Scotland

Tisseyre S., Le rôle de la bonne foi en droit des contrats, Essai d'analyse à la lumière du droit anglais et du droit européen, Editura Presses Universitaires d'Aix Marseille, Aix-enProvence, 2012

Ungureanu C.T., Contractul electronic, Revista Dreptul, nr. 9, 2015

Ungureanu C.T., Drept internaţional privat european în raporturi de comerţ internaţional, Editura Hamangiu, Bucureşti, 2021

Ungureanu C.T., Implicaţiile internetului în viaţa juridică, în Analele Ştiinţifice ale Universităţii „Alexandru Ioan Cuza” Iaşi, Tomul LXIII, Ştiinţe Juridice, nr. II, 2017

Zacks E.A., The restatement (Second) of contracts $\S 211$ : Unfulfilled expectations and the future of modern standardized consumer contracts, în Wayne State University Law School Legal Studies Research paper series no. 2016-14 